\title{
АМЕРИКАНСКАЯ МЕЧТА СЕРГЕЯ ЕСЕНИНА
}

\author{
SERGEI ESENIN'S AMERICAN DREAM
}

\author{
WAWRZYNIEC POPIEL-MACHNICKI, BARTOSZ OSIEWICZ
}

\begin{abstract}
AвSTRAст. The present paper is an attempt to interpret the works of Esenin, which were created under the influence of his journey to the United States of America in 1922 and 1923. The considerations are focused on the discussion about culture and civilization in the cultural aspect of Russia and America. The polemics between Esenin and Mayakovski has also been emphasized as the Black Man's author's foreign trip was to a large extent motivated by his willingness to prove his poetic superiority over the outstanding futurist.

Keywords: Esenin, Yesenin, Mayakovski, America, culture, civilization

Wawrzyniec Popiel-Machnicki, Uniwersytet im. Adama Mickiewicza w Poznaniu, Poznań - Polska,wawerpma@amu.edu.pl
\end{abstract}

ORCID ID: 0000-0002-3097-2615

Bartosz Osiewicz, Uniwersytet im. Adama Mickiewicza w Poznaniu, Poznań - Polska, osiebar@amu.edu.pl

ORCID ID: 0000-0003-2208-5386

Когда в 1922 году Сергей Есенин вместе со своей второй женой американской прима-балериной Айседорой Дункан решил совершить путешествие на Запад - в Германию, в Италию, во Францию, а в итоге поехал в Соединенные Штаты Америки, в России он был уже известным поэтом, а его слава не ограничивалась только литературными кругами. Личность Есенина сформировалась в деревенской среде, в которой чрезвычайно важными были вопросы духовной жизни, традиции, корней, веры и культуры предков. Вынесенные из родного рязанского дома воспитание и наука повлияли на то, что в литературных столицах России его начали отождествлять с представителями новокрестьянской поэтической волны. У него были широкие литературные и дружеские связи с выдающимися представителями этого направления в искусстве слова - Николаем Клюевым, Сергеем Клычковым, Александром Ширяевцем, Петром Орешиным. С первым из них, автором знаменитой поэмы Погорельщиина (1928-1929), Есенин читал стихи перед императорской семьей в салонах Царского села. Среди них были произведения, вошедшие в его первые, пользующие- 
ся огромной популярностью, поэтические сборники Радунициа (1916) и Сельский часослов (1918).

Уже с первых дней любители его творчества заметили, что Есенин вовсе не приверженец фольклорного искусства, а настоящий наследник поэтов XIX столетия - Николая Некрасова, Алексея Кольцова, Ивана Никитина, знаток крестьянской души. Рязанский поэт, как подчеркивает Валерий Земсков, „выступал перед слушателями в крестьянских одеждах, так же как и Клюев, считал эту стилизацию средством скорейшего завоевания литературной славы" [Земсков 1967: 147].

Не всем, однако, такая стилизация подходила, о чем свидетельствует критический отзыв Владимира Маяковского, которого Есенин уже с первых дней их знакомства считал поэтическим соперником. Знаменитый футурист так оценил выступления новокрестьянских поэтов: „В общем пошловато. Концерт несколько эгофутуричен, пейзаны очень далеки от подлинника. Декорации совершенно не идут к месту" [Земсков 1967: 147]. В книге Владимира Белоусова Сергей Есенин. Литературная хроника упомянут званый ужин у Федора Сологуба, на котором после выступления Маяковского попросили прочитать свои стихи молодого Есенина.

Слегка покраснев, крестьянским, избяным голосом он (Есенин - В.П.-М., Б.О.) прочитал несколько маленьких стихотворений о полях, о березах. Прочитал хорошо, скромно улыбаясь. А когда стали просить еще, заявил:

- Где же нам, деревенским, схватываться с городскими Маяковскими. У них и одежда, и щиблеты модные, и голос трубный, а мы ведь тихенькие, смиренные. - Да ты не ломайся, парень - пробасил Маяковский, - не ломайся, миленек, тогда и у тебя будут модные щиблеты, помада в кармане и галстук с аршин [Белоусов 1969: 97-98].

Эти воспоминания показывают, что автор Дымом половодье... (1910) стремился освободиться от „крестьянской ограниченности”, „«оторваться» от деревни и сблизиться с городом", но и это не позволило в те времена "подняться" до высот Маяковского [ср. Базанов, Прокушев 1975: 16-17].

Таким образом, очень быстро интерес к поэзии и стремление к известности заставили автора Ключей Марии (1918) развивать свое художественное дарование. Такой поэтической школой стали для него отношения с Анатолием Мариенгофом и Вадимом Шершеневичем, которые возглавляли авангардную художественную группировку имажинистов. Есенин скоро стал одним из поэтических лидеров авангардного искусства Серебряного века, а его изысканные ступенчатые метафоры заучивали наизусть. Такая слава его до конца не устраивала. Он мечтал о мировом признании и о том, чтобы его литературное credo, пропитанное русским духом, было замечено за пределами его родины [Базанов 1982: 
251]. За этой мечтой все время „таился” Маяковский. Когда Есенин узнал о том, что автор поэмы Облако $b$ штанах (1915) восхищается творчеством американского поэта Уолта Уитмена [см. Чуковский 1907; Уитмен $1911]^{1}$, признанного классика, а также реформатора и предшественника современной поэзии, на одном из банкетов произошла очередная стычка между поэтами. В воспоминаниях Николая Полетаева Есенин кричал:

- Россия моя, ты помнишь, - моя, а ты... ты американец! Моя Россия!

На что сдержанный Маяковский, кажется, отвечал:

- Возьми, пожалуйста! Ешь ее с хлебом!" [Земсков 1967: 156-157].

Есенин, по-видимому, не захотел отдавать „американское”, творческое предполье Маяковскому. В 1921 году, оценивая поэтическое дарование Маяковского, он признался:

Он поэт для чего-то, а я поэт от чего-то. Не знаю сам от чего... Он проживет до восьмидесяти лет, ему памятник поставят... А я сдохну под забором, на котором его стихи расклеивают. И все-таки я с ним не поменяюсь [Белоусов 1970: 11].

Это признание не до конца совпало с реальностью, и Есенин решил первым покорить океанские просторы. Этому способствовало появление в России Айседоры Дункан. Ее визит, подготовленный и использованный большевиками в политических целях, должен был помочь карьере американской танцовщицы, а неожиданно повлиял на жизненную и творческую судьбу русского поэта.

Брак Есенина с Дункан, которая была старше него на 18 лет, представлял собой союз близких друг другу артистов и далеких друг от друга людей [см. Klimowicz 2005: 204-211; Stern 2006]. Кроме культурной подоплеки он имел и практические последствия. Благодаря американке вышедший из народа русский поэт мог на время покинуть свою родину и увидеть Запад, в том числе США. Как внешний наблюдатель с душой славянофила, он пристально всматривался в новую для него действительность, которая представляла собой объект интереса западников. Американское путешествие Есенина продолжалось с октября 1922 по февраль 1923 года. С октября по декабрь поэт поездил по нескольким городам северо-восточных штатов Америки. Покинув Нью-Йорк, где он жил постоянно с 2 по 18 октября, Есенин навестил Бостон, Чикаго, Кливленд, Милуоки и Детройт [ср. Куняев, Куняев 2006: 295, 296-298]. Вернувшись в Нью-Йорк под Новый год, поэт принял участие, как оказалось, в скандальном выступлении на квартире еврейского поэта Ма-

1 В дореволюционной России поэзия Уолта Уитмена печаталась в переводах Корнея Чуковского и Константина Бальмонта. 
ни-Лейба в районе Бронкс в январе 1923 года [Ср.: Куняев, Куняев 2006: 298-307]. „Похабник и скандалист”, Есенин покинул США в начале февраля следующего года на борту парохода Джордж Вашингтон. За время пребывания в Америке поэт оставался в тени известной жены, с которой, в конечном итоге, порвал после их совместного возвращения в Россию.

Американский опыт Есенина заставляет обратиться к вопросам культуры и цивилизации, взаимосвязь и взаимодействие которых являются особо актуальными в контексте американского и русского пространств. Именно в них наблюдается перемещение акцентов между материальными и духовными аспектами человеческого существования. „Американские” произведения Есенина вписываются в антонимическое понимание культуры и цивилизации в бердяевском ключе [Mazurek, Pawlikowska 2000: 220]. Оно состоит в оппозиционном восприятии России и Запада, причем родина рязанского поэта ассоциируется с духовным началом, в отличие от западной культуры, в которой первостепенную роль начала играть механизированная цивилизация. Такая модель жизни для приверженцев славянофильской мысли была равнозначна разрушению общественных связей, ведущих „„к дезинтеграции личности” [Mazurek, Pawlikowska 2000: 220]. Оппозиции дух - материя, художественное творчество - техническое развитие свойственны есенинской мысли. Подтверждением этому является отсылающий к Гоголю критический отзыв об Америке.

В 1923 году в газете „Известия” был напечатан очерк Есенина под заглавием Железный Миргород. С первых строк эта прозаическая публикация переполнена восторгом перед Америкой. Как справедливо утверждает Александр Эткинд,

у Есенина в Миргороде есть наивное и откровенно восторженное восхищение американской роскошью, американским масштабом, просто большими коридорами на корабле. Он никогда такого не видел, и он постоянно сравнивает вот эту роскошь, золото, бархат, а главное, эти пространства, где нет тесноты с грязью русского крестьянина, к которым привык. Такие непосредственные противопоставления характерны для человека, который первый раз все это видит [см. Абаринов 2015].

Тем самим, читателя не могут не удивлять строки из Железного Миргорода, в которых автор нарисовал картину, вызвавшую сильные эмоциональные впечатления. Нетрудно заметить, однако, что восторг Есенина поверхностный. Он пишет:

Перед Америкой мне Европа показалась старинной усадьбой [Есенин 1979, V: 142]; На наших улицах слишком темно, чтобы понять, что такое электрический свет Бродвея. Мы привыкли жить под светом луны, жечь свечи перед иконами [Есенин 1979, V: 147]; 
Если взглянуть на ту беспощадную мощь железобетона, на повисший между двумя городами Бруклинский мост, высота которого над землей равняется высоте 20-этажных домов, все же никому не будет жаль, что дикий Гайавата уже не охотится здесь за оленем [Есенин 1979, V: 147-148];

Сейчас Гайавата - этнографический киноартист; он показывает в фильмах свои обычаи и своё дикое несложное искусство [Есенин 1979, V: 148].

Необходимо, однако, подчеркнуть, что восхищение американской индустриализацией имеет определенную подоплеку. Рассказчик, на самом деле, адресует эти слова своему литературному сопернику:

Мать честная! До чего бездарны поэмы Маяковского об Америке! Разве можно выразить эту железную и гранитную мощь словами?! Это поэма без слов. Рассказать ее будет ничтожно. Милые, глупые российские доморощенные урбанисты и электрификаторы в поэзии! Ваши «кузницы» и ваши «лефы» как Тула перед Берлином или Парижем [Есенин 1979, V: 144];

Мне смешны поэты, которые пишут свои стихи по картинкам плохих американских журналов [Есенин 1979, V: 148].

Литературный герой Есенина заявляет, что в поэтической гонке он обогнал своего соперника, подчеркивая, что футуристические стихи Маяковского оторваны от реальной действительности. Намек на эту же тему мы найдем также в одной из частушек, которую Есенин сочинил еще до отъезда в Америку. В ней он старался убедить читателей в том, что городская поэзия далека от правды:
Ах, сыпь, ах, жарь,
Маяковский - бездарь.
Рожа краской питана,
Обокрал Уитмана.
[Коржан 1967: 344]

Есенин не был бы настоящим мастером слова, если бы Железный Миргород являлся лишь частной перекличкой с Маяковским, а ироническая частушка обвинением футуриста в подражании Уитмену. В тексте этого очерка читатель найдет описание многих картин будничной жизни Америки, которые уже не вызывали восторга у поэта.

Ссылка на Гайавату - коренного жителя Америки - дает возможность увидеть в тексте намек на историю США. Это отражается в словах Есенина, которые дают критическую оценку увиденного и осмысленного поэтом:

Туда потянулся весь неудачливый мир Европы, искатели золота и приключений, авантюристы самых низших марок... и теснили (они - В.П.-М., Б.О.) коренной красный народ Америки всеми средствами [Есенин 1979, V: 147]. 
Есенинский повествователь называет колонизаторов Америки „белым дьяволом". Индустриализация, которая, с одной стороны, восхищает, с другой - доводит до представления американцев как народа „весьма примитивного со стороны внутренней культуры" [Есенин 1979, V: 150]. Отсутствие ее - это самое страшное, с чем поэт не может смириться.

В письме Анатолию Мариенгофу из Нью-Йорка от 12 ноября 1922 года Есенин писал, что русская душа, являющаяся синонимом русского национального характера, славянского менталитета, православного вероисповедования, в Америке совершенно непонятна и чужда. Есенин писал другу:

Милый мой Толя! Как рад я, что ты не со мной здесь в Америке, не в этом отвратительном Нью-Йорке. Было бы так плохо, что хоть повеситься. // Изадора прекраснейшая женщина, но врет не хуже Ваньки. Все ее ба́нки и за́мки, о которых она пела нам в России, - вздор. Сидим без копеечки, ждем, когда соберем на дорогу и обратно в Москву. // Лучше всего, что я видел в этом мире, это все-таки Москва. В чикагские «сто тысяч улиц» можно загонять только свиней. На то там, вероятно, и лучшая бойня в мире. / / О себе скажу (хоть ты все думаешь, что я говорю для потомства): что я впрямь не знаю, как быть и чем жить теперь. / / Раньше подогревало то при всех российских лишениях, что вот, мол, «заграница», а теперь, как увидел, молю бога не умереть душой и любовью к моему искусству. Никому оно не нужно, значение его для всех - как значение Изы Кремер, только с тою разницей, что Иза Кремер жить может на свое пение, а тут хоть помирай с голоду. // Я понимаю теперь, очень понимаю кричащих о производственном искусстве. // В этом есть отход от ненужного. И правда, на кой черт людям нужна эта душа, которую у нас в России на пуды меряют. Совершенно лишняя штука эта душа, всегда в валенках, с грязными волосами и бородой Аксенова. С грустью, с испугом, но я уже начинаю учиться говорить себе: застегни, Есенин, свою душу, это так же неприятно, как расстегнутые брюки [Есенин 1979, VI: 133].

В переписке с Мариенгофом также подтверждается, что автора $\mathrm{Pa}$ дуницы (1916) очень быстро настигла суета и ностальгия, вызванные невообразимой тоской по Родине. Такое состояние души будет характерным для представителей всех волн русской эмиграции в XX веке. Однако Есенин не был и не мог стать эмигрантом. Предвосхищая опыт своих собратьев по перу, за пределами Родины он понял, что не может существовать в чужой культурной и языковой среде. Вместо освещенных электрическими прожекторами нью-йоркских небоскребов Есенин предпочитал тепло русской деревенской хаты. Поэт писал Мариенгофу:

Милый Толя. Если б ты знал, как вообще грустно... [...] В голове у меня одна Москва и Москва. // Даже стыдно, что так по-чеховски. / / Сегодня в американской газете видел очень большую статью с фотографией о Камерном театре, но, что там написано, не знаю, за не... никак не желаю говорить на этом проклятом английском языке. Кроме русского, никакого другого не признаю, и держу 
себя так, что ежели кому-нибудь любопытно со мной говорить, то пусть учится по-русски. // Конечно, во всех своих движениях столь же смешон для многих, как француз или голландец на нашей территории. // [...] / / Вижу милую, остывшую твою железную печку, тебя, покрытого шубой, и Мартышан. / / Боже мой, лучше было есть глазами дым, плакать от него, но только не здесь, не здесь. Все равно при этой культуре «железа и электричества» здесь у каждого полтора фунта грязи в носу [Есенин 1979, VI: 134].

Языковой и цивилизационный барьеры, не позволявшие Есенину погрузиться в американские культурные сферы, вызвали у него фрустрацию и повлияли на отрицательную оценку жителей США, в которых он видел только простую толпу, заинтересованную лишь в погоне за деньгами. Такими наблюдениями он делится с другом в следующих строках своей переписки:

Здесь имеются переводы тебя и меня в издании Modern Russian Poetry, но все это убого очень. Знают больше по имени, и то не американцы, а приехавшие в Америку евреи. По-видимому, евреи самые лучшие ценители искусства, потому ведь и в России, кроме еврейских девушек, никто нас не читал [Есенин 1979, VI: 135].

Есенин больно переживал то, что, как утверждает Дитц,

его стихи, вошедшие в антологию русской поэзии, которая была выпущена в Нью-Йорке, вызывают полное разочарование, даже горечь и обиду: механический перевод ничего не оставлял от чистоты и свежести задушевных, очень русских есенинских строк. Неповторимое национальное своеобразие его лирики бесследно исчезло в косноязычных оборотах чужого языка... [Дитц 1990: 162].

Рязанский поэт начинал осознавать, что отсутствие понимания за границей его поэтического дарования идет наперекор его международной славе. Как справедливо утверждает Оксана Лыткина, „Есенин отмечает примитивность внутренней культуры американцев, владычество доллара и «Business». Называя Америку Миргородом, автор подчеркивает ее духовную и социальную отсталость" [Лыткина 2009: 218].

Литературная критика, описывая американский эпизод жизни автора Пугачева (1921), очень часто сосредоточивалась на оценке будничного поведения поэта и его отношений с Дункан. Примером могут послужить хотя бы две книжки: Ильи Шнейдера, в которой история Есенина и Дункан пропитана идеологией советских времен [Шнейдер 1974], и научно-популярная, скорее публицистическая работа Кароли Стерн, в которой в поэтике „желтой прессы” описываются преимущественно элементы биографии Есенина [Stern 2006].

Стоит, однако, проанализировать произведения автора Кобыльих кораблей (1919), сочиненные им приблизительно в этот период, чтобы уви- 
деть и понять все терзающие его душу нюансы. Как утверждает Владимир Дитц, „самые «кабацкие», самые «скандальные» стихи были написаны Есениным не в Москве, не в России, а за границей. И нет сомнения, что на них лежит и налет впечатлений от европейских и американских вертепов" [Дитц 1990: 160].

Действительно, заграничная поездка рязанского поэта оставила неизгладимый след в его творчестве. Однако утверждения литературоведа невольно носят идеологический отпечаток. Попытка ограничивать так называемые „кабацкие” стихотворения только американским контекстом является слишком упрощенной. Нельзя подчеркивать, что поэтическое отрицание Есениным окружающей действительности было вызвано несправедливостью, с которой он столкнулся за океаном. Поэт, совершая свое путешествие, невольно сосредоточился на картинах, которые не совпадали с его славянофильским мировоззрением. Видно это и в других произведениях, хотя бы в поэме Страна негодяеb (1922-1923), в которой комиссар Рассветов колоритно приблизил читателю Соединенные Штаты и их население:

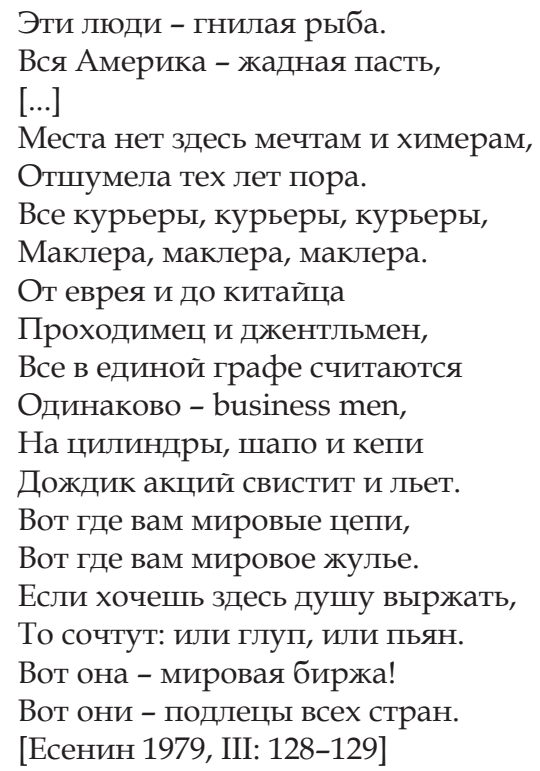

Приведенные строки говорят о человеке, который очутился в стране, где царствует доллар, притягивающий из всего мира тех, которые заблудились в погоне за ним. Америка для героя Есенина это страна, в которой нет места для пропитанного стихотворной душой человека. Однако необходимо заметить, что в этой же Стране негодяев читатель 
найдет строки, напоминающие Железный Миргород и отсылающие к бердяевским идеям:
Мы, конечно, во многом отстали.
Материк наш:
Лес, степь да вода.
Из железобетона и стали
Там настроены города.
Вместо наших глухих раздолий,
Там, на каждой почти полосе,
Перерезано рельсами поле
С цепью каменных рек - шоссе.
И по каменным рекам без пыли,
И по рельсам без стона шпал
И экспрессы и автомобили
От разбега в бензинном мыле
Мчат, секундой считая доллар...
[Есенин 1979, III: 128].

Возникает вопрос, что лучше для есенинского лирического героя: „лес, степь да вода" или железобетонная технократическая цивилизация, которая мчится в погоне за царствующим долларом? Ответ заключается в том, что Есенин никогда не уделял особого внимания ни деньгам, ни материальным благам. Общеизвестно, что характерологические черты поэта не только не позволили ему создать прочный домашний очаг, но влияли на равнодушное отношение к экономической обеспеченности. Самым ценным была для него правдивость его стихов, связь с реальной жизнью, которую он старался пропитать крестьянской лирической тонкостью. Ведь, возможно, поэтому он и решил поехать в Америку, чтобы лично убедиться в том, как выглядит заграница, как там примут его поэтическое слово и поймут ли его смысл. Он подозревал, что могут быть с этим трудности, о чем свидетельствует краткий сатирический стишок 1921-1922 годов Американским ароматом...

\footnotetext{
Американским ароматом

Пропитан русский аромат.

Покрыть бы „АРУ” русским матом -

Поймет ли „АРА” русский мат?!

[Есенин, Американским... $]^{2}$
}

2 Текст цитируется по публикации на сайте http:/ / esenin.velchel.ru, здесь же размещен комментарий к стихотворению. Первая публикация - „в газете «Русь святая», Липецк, 1993, 23 сент. - 6 окт., № 22/23, с. 5 (в заметке В. Кузнецовой «Экспромт Есенина»). Печатается и датируется по авторизованной машинописи В. П. Комардёнкова «Воспо- 
После первой мировой войны в Европе работала американская гуманитарная организация APA (ARA, American Relief Administration), которая в начале 20-х годов получила разрешение на свою деятельность в России. Однако наряду с официальной деятельностью, она, по слухам, занималась шпионажем [см. Макаров, Христофоров]. Есенин парафразировал эту историю, подчеркивая, что стена непонимания между Россией и Америкой слишком высока и непроницаема. Чувство отчуждения вызывает тоску, следы которой читатель найдет в очередных поэтических строках:

В мать тебя, из мати в мать

Стальная Америка!

Хоть бы песню услыхать

Да с родного берега.

[Есенин, В мать...]

Родной берег является для поэта бесценным местом, в дали от которого его поэтическая душа усыхает. Он покинул этот берег, чтобы найти для себя „модные щиблеты”, которые в молодости он видел на ногах у Маяковского. В стихотворении Ты прохладой меня не мучай (1923) лирический герой Есенина возвращается к этой теме:

Было время, когда из предместья

Я мечтал по-мальчишески - в дым,

Что я буду богат и известен

И что всеми я буду любим.

Да! Богат я, богат с излишком.

Был цилиндр, а теперь его нет.

Лишь осталась одна манишка

С модной парой избитых штиблет.

[Есенин 1979, I: 223]

Литературная дуэль Есенина с Маяковским расходится с историей, которую написала судьба для поэтов. Есенин, оказавшись в Америке, приобрел жизненный и литературный опыт, с которым он мог встать в один ряд с автором поэмы 150000 000. Однако, как показала история, Маяковский, в некоторой степени, стал подражателем Есенина. Об этом свидетельствуют многие произведения русского футуриста, в которых он критически описал Америку, невольно пользуясь есенинскими аргументами [см. Parafianowicz 2014: 89-103].

минания» (РГАЛИ, Коллекция мемуаров и дневников, ф. 1337, оп. 3, ед. хр. 49, с. 246)" [Есенин 1921-1922]. 
После американского путешествия Есенин прекрасно понял, что является для него настоящей ценностью. Рассказал о ней в 1924 году корректору Госиздата, который работал над его Москвой кабацикой:

- Знаешь, почему я - поэт, а Маяковский так себе - непонятная профессия? У меня родина есть! У меня - Рязань. Я вышел оттуда и, какой ни на есть, а приду туда же! А у него - шиш. Вот он и бродит без дорог и ткнуться ему некуда. Ты меня извини, но я постарше тебя. Хочешь добрый совет получить? Ищи родину! Найдешь - пан! Не найдешь - все псу под хвост пойдет! Нет поэта без родины... [Белоусов 1970: 120].

В этих словах заключается суть есенинских поэтических поисков. Когда он появился в столичных салонах и столкнулся с представителями авангардного искусства, в том числе с Маяковским, он захотел стать одним из них - настоящим поэтом. Не оставляло его волнение, что крестьянский дух, к которому неоднократно многие приклеивали ярлык фольклорности и деревенского лубка, будет для него якорем. Однако поэт не понимал, что этот якорь выполняет двойственную функцию. С одной стороны подчеркивает то, что автор поэмы Черный человек (1925) является истинно русским поэтом, о чем он убедился в Америке. С другой стороны, деревенская родословная стала нравственным стержнем, который противостоял революционной идеологии и не подвел Есенина до последних дней его жизненного и творческого пути. И именно это стало залогом его настоящей поэтической славы.

\section{Библиография}

Абаринов В. 2015. Америка глазами русских писателей: Есенин в США, электронный ресурс: https:/ / www.svoboda.org/a/27060472.html (доступ 21.08.2017).

Базанов В. 1982. Сергей Есенин и крестьянская Россия, Ленинград: Советский писатель. Базанов М., Прокушев Ю. (ред.) 1975. Есенин и современность, Москва: Современник. Белоусов В. 1969. Сергей Есенин. Литературная хроника, ч. I, Москва: Сов. Россия. Белоусов В. 1970. Сергей Есенин. Литературная хроника, ч. II, Москва: Сов. Россия. Дитц В. Ф. 1990. Есенин В Петрограде-Ленинграде, Ленинград.

Есенин С. А. 1977-1980. Собрание сочинений в шести томах, Москва: Художественная литература.

Есенин С. А. 1921-1922. Американским ароматом..., электронный ресурс: http:/ / esenin. velchel.ru/index.php?cnt=5\&rhime=sa_74 (доступ 21.08.2017).

Есенин С. 1923. В мать тебя, из мати в мать..., электронный ресурс: http:/ / esenin.niv. $\mathrm{ru} /$ esenin/text/stihi/raznoe/stih-zapisannoe-25.htm (доступ 21.08.2017).

Земсков В. Ф. 1967. Есенин и Маяковский (К истории взаимоотночений), [в:] В. Г. Базанов (ред.), Есенин и русская поэзия, Ленинград: Наука.

Коржан В. В. 1967. Забытые частушки Есенина, [в:] В. Г. Базанов (ред.), Есенин и русская поэзия, Ленинград: Наука. 
Куняев С. Ю., Куняев С. С. 2006. Сергей Есенин, Москва: Молодая гвардия.

Лыткина О. И. 2009. Образ Америки В русской языковой картине мира, „Ученые записки Российского государственного социального университета", № 4.

Макаров В. Т., Христофоров В. С. 2006. Новые данные о деятельности Американской администрачии помощи (АРА) в России, „Новая и новейшая история”, № 5, электронный ресурс: http://vivovoco.astronet.ru/VV/JOURNAL/NEWHIST/ARA. НТМ (доступ 23.10.2017).

Уитмен У. 1911. Побеги травы: Стихотворения, пер. с англ. и предисл. К. Д. Бальмонта, Москва: Изданіе Кружка Молодыхъ.

Чуковский К. И. 1907. Поэт-анархист Уот Уитман, пер. в стихах и характеристика, Санкт-Петербург.

Шнейдер И. 1974. Встречи с Есениным, Москва: Советская Россия.

Klimowicz T. 2005. Pożar serca. 16 smutnych esejów o miłości, o pisarzach $i$ ich muzach, Wrocław: Wydawnictwo Uniwersytetu Wrocławskiego.

Mazurek S., Pawlikowska Z. 2000. Культура/циивилизациия, [в:] A. de Lazari (ред.), Идеи b Poccuu / Idee w Rosji / Ideas in Russia. Leksykon rosyjsko-polsko-angielski, t. 3, Łódź: Ibidem.

Parafianowicz H. 2014. Włodzimierz Majakowski i jego „odkrycie” Ameryki, „Studia Wschodniosłowiańskie", t. 14.

Stern C. 2006. Poeta i tancerka. Isadora Duncan i Siergiej Jesienin, przeł. U. Szymanderska, Warszawa: Twój Styl. 